\title{
FINANCIAL LITERACY ON SMALL AND MICRO BUSINESS OF THE INDIGENOUS PEOPLE OF PAPUA IN JAYAPURA CITY
}

\begin{abstract}
This study is a quantitative study that aimed to find the level of financial literacy of Papuan Micro, Small, and Medium Enterprises (MSME) and the factors that influence it. The sample consisted of 75 respondents of MSME actors in Jayapura city at Pasar Mama-Mama Papua. The data was analyzed using multiple linear regression method with SPSS version 22.0. The results showed that (1) the level of financial literacy in Jayapura city is low, (2) there is no influence of gender towards the level of financial literacy, (3) there is an influence of last educational level towards the level of financial literacy, (4) there is no influence of monthly profit towards the level of financial literacy, (5) there is an influence of investment towards the level of financial literacy, (6) there is an influence of borrowing and saving in bank towards the level of financial literacy, (7) there is an influence of insurance towards the level of financialliteracy.
\end{abstract}

Keywords: financial literacy, gender, education, profit, investment, borrowing and saving, insurance.

\section{INTRODUCTION}

The world today is facing not only a global crisis, but also a financial crisis. A few years ago some countries had discussed about the financial literacy which cannot be separated by the increase of the population. Moreover, the lack of financial literacy is considered to be one of the factors that affect financial decision-making, and its less information may have a negative impact. According to the Indonesian Financial Services Authority (OJK) survey in 2013 and 2016, the level of financial literacy in Indonesia is improving, for instance, the ratio in 2013 was $21.8 \%$, and in 2016 it i increased by $29.7 \%$ (Otoritas Jasa Keuangan,

\footnotetext{
${ }^{1}$ Anita Erari, Dr Faculty of Economy and Business, Department of Management, Universitas Cenderawasih, Jl. Kamp. Wolker, Waena, Jayapura, 99358, Papua, Indonesia; e-mail: aerari@yahoo.co.id (corresponding author). ORCID: 0000-0002-4758-087X.

${ }^{2}$ Kurniawan Patma, M.Ak, Faculty of Economy and Business, Department of Accountancy, Universitas Cenderawasih, Jl. Kamp. Wolker, Waena, Jayapura, 99358, Papua, Indonesia; e-mail: patmakurniawan@gmail.com. ORCID: 0000-0001-7226-8047.

3 Ramasoyan Arung Lamba, M.Ak, Faculty of Economy and Business, Department of Accountancy, Universitas Cenderawasih, J1. Kamp. Wolker, Waena, Jayapura, 99358, Papua, Indonesia; e-mail: ramajr88@gmail.com. ORCID: 0000-0002-2443-5354.
} 
2017). The citizen should be able to manage their finances and its practice wisely due to follow the financial market development. Hence, financial literacy is needed for the citizen since it is related to personal economic and has a purpose to manage the financial in a proper way, thus it can fulfill people's necessity and prosperity.

The law regulation on the Authority of financial service (No. 21/2011) has mandated OJK to manage and supervise the financial service industry. OJK is also mandate to protect the community interest while interacting with the financial service industry. The main purpose of the national financial literacy strategy is to create Indonesian citizenship with high financial literacy level (well literate). Thus, the community can choose and utilize a product and a financial service to increase the welfare (Welly et al., 2018). Moreover, by utilizing various financial sectors and managing finances properly according to the needs will help to reduce the lack of knowledge on low literacy.

There are some factors that influence financial literacy, those are; (a) age, (b) work experience, (c) mother's education, and (d) department (Ansong and Gyensare, 2012). While, Margaretha and Pambudhi (2015) found that gender, GPA, and parents' income on financial literacy level as the financial literacy factors also play an important role. Another study by Sucuahi (2013) stated that age, spending habit, gender, faculty, and college year entry affect the financial literacy. Meanwhile, according to OJK, the factors that influence financial literacy are: (1) gender, (2) education level, and (3) income level (Otoritas Jasa Keuangan, 2017). From some previous studies above, the dominant factor is gender. Gender really determines whether the person understands literacy or not.

According to Amaliyah and Witiastuti (2015) found that gender and education have significant influence on the literacy level of MSME owner compared to the income level. They found that the financial literacy of male MSME owners is higher than female MSME owners. Whereas, Aribawa(2016) in his research stated that there is the effect of financial literacy on the performance and the sustainability of MSME business. It shows that good financial literacy is expected to be able to make decision of correct management and financial to improves the performance and sustainable of business.

Desiyanti (2016) stated that the financial understanding and literacy are very needed in this business world. Moreover, she claimed that the understanding of financial products in implementing the business world is also needed. She found that the financial product with the highest utility index value is the financial bank product (savings dominated) and the lowest product is the product of capital market financial.

According to BPS data of 2020, the citizen of Jayapura city which understanding of financial literacy only $14.2 \%$ from the total of Jayapura city community which has utilizing the product and service of finance institutions. This research is aimed to determine the effect of the determinants of financial literacy on the level of financial literacy. The financial literacy is also announcing the product of financial service such as investment, saving and borrowing and insurance. The financial literacy can connect the citizen welfare, especially the actors in the MSME sector and avoid from the financial investment activity which not clear such as avoiding of various illegal financial service providers (which is not registered/not having an official license with OJK) in their operations.

In this research, besides seeing on what is the role of fincancial institution product against financial literacy of Papuan MSME actors in Jayapura city, especially the MamaMama Papua market traders, the researchers also look at the characteristics of Papuan MSME actors such as gender, education level, and income. The understanding on financial literacy is needed for the business actors, especially for the MSME owners. The MSME 
business owner becomes the target of open access in financial institutions or can be referred to as financial inclusion because MSME is one of the supporting factors of economic country to open new jobs and reduce the number of unemployment and crime. Therefore, the objective of this study is to analyze the factors of financial literacy knowledge of Papuan MSME actors in Jayapura city in order to avoid financial risks and take advantage of the role of financial institutions.

\section{RESEARCH HYPOTHESIS}

H1: It is suspected that gender affects the level of financial literacy of MSME actors in Jayapura City (Mama-Mama Papua market traders).

H2: It is suspected that educational background affects the level of financial literacy among Papuan Indigenous Micro and Small Business actors in Jayapura City (Mama-Mama Papua market traders).

H3: It is suspected that the amount of income affects the level of financial literacy of Papuan Indigenous Micro and Small Business actors in Jayapura City (Mama-Mama Papua market traders).

H4: It is suspected that investment knowledge affects the level of financial literacy among Papuan Indigenous Micro and Small Business actors in Jayapura City (Mama-Mama Papua market traders).

H5: It is suspected that knowledge of saving and borrowing affects the level of financial literacy among Papuan Indigenous Micro and Small Business actors in Jayapura City (Mama-Mama Papua market traders).

H6: It is suspected that the use of insurance affects the level of financial literacy among Papuan Indigenous Micro and Small Business actors in Jayapura City (Mama-Mama Papua market traders).

\section{METHODOLOGY}

This study used a quantitative approach with survey research as the methodology. The survey research is a research which takes a sample from a population and uses a questionnaire as the research tools. The questionnaire is measured using the Likerts scale. The respondents are taken from traders who have a license to trade within the market. Random sampling techniques are used to draw samples from 180 Mama-Mama Papua market traders and obtained 75 Papuan MSMEs traders a sample study. The data are collected through questionnaires which were distributed in two ways: a). the questionnaires are distributed directly to the traders in Mama-Mama Papua market, and b) the questionnaires are distributed directly to shopkeepers who are believed as the wholesaler. The collected data are analyzed using descriptive analysis and Likert Scale to know the level of financial literacy of Papuan MSMEs actors in Mama - Mama Papua market in Jayapura city.

\section{RESULT}

\section{The instrument test}

The instrument test is implemented to know whether the research instrument has met the criteria of validity and reliability. The following is a test of reliability and validity. 


\section{a) Validity Test}

Validity test is done to determine whether the questions are valid or not. The validation can be seen through person correlation which stated "valid" if the coefficient is greater or similar with 0.227 . The result of validity test is seen in table 1 below:

Table 1. Recapitulation of questionnaire validity test

\begin{tabular}{|c|c|c|c|}
\hline Variable & Item & Person Correlation & Information \\
\hline \multirow{11}{*}{$\begin{array}{l}\text { Basic Knowledge of } \\
\text { Finance }(Y)\end{array}$} & Q1 & 0.556 & VALID \\
\hline & Q2 & 0.527 & VALID \\
\hline & Q3 & 0.542 & VALID \\
\hline & Q4 & 0.654 & VALID \\
\hline & Q5 & 0.667 & VALID \\
\hline & Q6 & 0.568 & VALID \\
\hline & Q7 & 0.219 & INVALID \\
\hline & Q8 & 0.272 & VALID \\
\hline & Q9 & 0.390 & VALID \\
\hline & Q10 & 0.544 & VALID \\
\hline & Q11 & 0.452 & VALID \\
\hline \multirow{5}{*}{ Investment (X4) } & Q12 & 0.318 & VALID \\
\hline & Q13 & 0.670 & VALID \\
\hline & Q14 & 0.658 & VALID \\
\hline & Q15 & 0.836 & VALID \\
\hline & Q16 & 0.692 & VALID \\
\hline \multirow{7}{*}{ Saving and borrowing (X5) } & Q18 & 0.661 & VALID \\
\hline & Q19 & 0.518 & VALID \\
\hline & Q20 & 0.432 & VALID \\
\hline & Q21 & 0.540 & VALID \\
\hline & Q22 & 0.602 & VALID \\
\hline & Q23 & 0.682 & VALID \\
\hline & Q24 & 0.393 & VALID \\
\hline \multirow{6}{*}{ Insurance (X6) } & Q25 & 0.279 & VALID \\
\hline & Q26 & 0.805 & VALID \\
\hline & Q27 & 0.479 & VALID \\
\hline & Q28 & 0.626 & VALID \\
\hline & Q29 & 0.501 & VALID \\
\hline & Q30 & 0.615 & VALID \\
\hline
\end{tabular}

Source: Processed primary data, R table.

Based on the table 1 above, there is an invalid question within the basic knowledge of financial literacy $(\mathrm{Y})$ variable. The question number $7(\mathrm{Q} 7)$ is invalid since its correlation 
is smaller than the R table, that is, $0.219<227$. While the other questions question within the $\mathrm{Y}$ variable are considered valid, because the person correlation is > alpha 0.227 . In investment variable (X4), all questions are considered valid with person correlation is greater than 0.227 (> 0.227). Similar to X4, saving and borrowing (X5) and insurance (X6) variables are also showed valid questions with person correlation $>0.227$. Based on the four variables above, it can be concluded that the questionnaire used in this study has total of 30 question with 29 valid questions and an invalid question.

\section{b) Reliability Test}

The reliability measurement within this study is done with cronbach's alpha score $>0.060$ which included in sufficient reliability level. If the cronbach's alpha coefficient is less than 0.060 then the instrument is considered as not reliable and vice verse. The result is written in table 2 below:

Table 2. Recapitulation of reliability test result

\begin{tabular}{|c|c|c|}
\hline Variable & Coefficient Cronbach's Alpha & Information \\
\hline Basic Knowledge of Finance & 0.670 & RELIABLE \\
\hline Investment & 0.716 & RELIABLE \\
\hline Saving and borrowing & 0.610 & RELIABLE \\
\hline Insurance & 0.616 & RELIABLE \\
\hline
\end{tabular}

Source: Processed Primary Data.

Based on the table 2 above, it is known that the entire variable is declared reliable because the cronbach's alpha coefficient is bigger than $0.060(>0.060)$. However, the question number $25(\mathrm{Q} 25)$ within the X4 variable cannot be included in the reliability test because it can affect the reliability of the data. Thus, during the reliability test, Q25 is not included.

\section{Classic assumption test}

\section{a) Normality Test}

Normality test is implemented with the Kolmogorov-Smirnov test. The data can be declared as normally distributed if the sig. value is bigger than $0.05(>0.05)$. The normality test is analyzed using the SPSS statistical 22 application and obtained the result that all variables, variables $\mathrm{X}$ toward $\mathrm{Y}$, are normally distributed with the significance level of 0.200 bigger than $0.05(0.200>0.05)$.

\section{b) Multicollinearity Test}

Multicollinearity test is aimed to test whether the regression model has a correlation between the independent variables. The availability of multicollinearity can be seen from the tolerance value or the variance inflation factor (VIF) value. If the tolerance value is bigger than $10 \%$ and VIF value is smaller than 10 , it can be said that the regression model is free from multicollinearity problems. In this study, multivollinearity test is done using SPSS statistic 22 aplication and obtained that the tolerance value of four independent variables is above 0.10 and the VIF value is less than 10 . Thus, it can be concluded that all independent variables have no symptoms of multicollinearity. 


\section{c) Heteroscedasticity Test}

Heteroscedasity test is used to test whether in regression model has an imbalance variance from residual observation of one and another. If the sig. value of independent variable is bigger than 0.05 (> 0.05) then there is no heteroscedasticity. The result of heteroscedasticity test showed that the probability of all independent variables is more than 0.05 or $5 \%$, thus the regression model of the heteroscedasticity is free.

\section{d) Autocorrelation Test}

In this research, the autocorrelation test is using Durbin-Watson test. It is said to pass the autocorrelation test if the DW is between the values of DU and 4-DU. Based on the test, it is known that the value of Durbin-Watson is 1.932 and the value of 4-DU (1.8013) is 2.1987, which means that it passes the autocorrelation test.

\section{Hypothesis Test}

a) Determination Coefficient $\left(\mathbf{R}^{2}\right)$

Determination coefficient is used to know the relationship between the independent variable and the dependent variable. $R^{2}$ value is located between 0 to $1\left(0 \leq R^{2} \leq 1\right)$. The purpose is to determine the effect of independent variable on the dependent variable by using the application of SPSS statistics 22. The results showed that the $\mathrm{R}$ square value is 0.414 , which means that independent variable can explain the dependent variable for 0.414 or $41.4 \%$ while the rest of $58.6 \%$ is influenced by other variable outside the model or cannot explained within this study.

b) Simultaneous Significant Test (F Test)

The $\mathrm{F}$ test in this study has purpose to determine the effect of gender, education, income, investment, saving and borrowing, and insurance together on the level of financial literacy. The way to test it, is by looking at the column $\mathrm{F}$ and the significance value contained in the ANOVA table. The result of $\mathrm{F}$ test can be seen in following table 3 below:

Table 3. Simultaneous significant test (F Test)

\begin{tabular}{|c|c|c|c|}
\hline Model & Variable & F count & F table \\
\hline $\mathrm{X}_{1}-\mathrm{Y}$ & Gender Type & 8.011 & 2.23521 \\
$\mathrm{X}_{2}-\mathrm{Y}$ & Latest Education & 8.011 & 2.23521 \\
$\mathrm{X}_{3}-\mathrm{Y}$ & Monthly Income & 8.011 & 2.23521 \\
$\mathrm{X}_{4}-\mathrm{Y}$ & Investment & 8.011 & 2.23521 \\
$\mathrm{X}_{5}-\mathrm{Y}$ & Saving and Borrowing & 8.011 & 2.23521 \\
& Insurance & 8.011 & \\
$\mathrm{X}_{6}-\mathrm{Y}$ & & & 2.23521 \\
\hline
\end{tabular}

Source: Processed primary data.

Based on the table 3 above, it can be concluded that F count is (7.662) > F table (2.23521) which means the hypothesis is accepted.

Hypothesis test is done to know whether there is influence between independent and dependent variable. T test is used to test the hypotheses by comparing the significant level (Sig. $t$ ) of each independent variables with sig. value $\alpha=0.05$. If the sig. $t$ is smaller than $\alpha=0.05$, then the hypothesis is accepted or there is significant influence between independent and dependent variable. Otherwise, if the sig $\mathrm{t}$ is bigger than $\alpha=0.05$ then the 
hypothesis is rejected or there is no significant influence between independent and dependent variable.

The financial literacy level of micro small business actors Papuans in Jayapura city

The descriptive analysis result for financial literacy of Papuan MSMEs actor in Jayapura city can be seen in statistic descriptive table below.

Table 4. Statistic Descriptions

\begin{tabular}{|c|l|c|c|c|c|}
\hline No. & \multicolumn{1}{|c|}{ Variable } & MIN & MAX & MEAN & $\begin{array}{c}\text { Std. } \\
\text { Deviation }\end{array}$ \\
\hline 1 & Basic Knowledge of Finance & 27.00 & 42.00 & 36.5467 & 3.42208 \\
\hline 2 & Investment & 13.00 & 24.00 & 20.4133 & 2.27853 \\
\hline 3 & Saving and Borrowing & 19.00 & 28.00 & 23.3467 & 2.22694 \\
\hline 4 & Insurance & 10.00 & 21.00 & 15.1600 & 2.26632 \\
\hline
\end{tabular}

Source: Processed primary data.

The frequency of financial literacy variable can be seen in the table 5 below that shows the percentage of financial literacy level for all variables.

Table 5. Frequency of financial literacy level

\begin{tabular}{|c|c|c|c|}
\hline Category & Total Value X & Frequency (People) & Percentage $(\%)$ \\
\hline \multicolumn{4}{|c|}{ Basic knowledge of finance } \\
\hline High & $X>37$ & 36 & $48 \%$ \\
\hline Medium & $32 \leq \mathrm{X} \leq 37$ & 33 & $44 \%$ \\
\hline Low & $\mathrm{X}<32$ & 6 & $8 \%$ \\
\hline \multicolumn{4}{|c|}{ Investment } \\
\hline High & $X>20,33$ & 40 & $53.33 \%$ \\
\hline Medium & $16,67 \leq X \leq 20,33$ & 32 & $42.67 \%$ \\
\hline Low & $X<16,67$ & 3 & $4 \%$ \\
\hline \multicolumn{4}{|c|}{ Saving and Borrowing } \\
\hline High & $X>25$ & 26 & $34.67 \%$ \\
\hline Medium & $22 \leq X \leq 25$ & 27 & $36 \%$ \\
\hline Low & $X<22$ & 22 & $29.33 \%$ \\
\hline \multicolumn{4}{|c|}{ Insurance } \\
\hline High & $X>17.67$ & 16 & $21.33 \%$ \\
\hline Medium & $14,33 \leq X \leq 17.67$ & 29 & $38.67 \%$ \\
\hline Low & $X<14,33$ & 30 & $40 \%$ \\
\hline
\end{tabular}

Source: Processed primary data.

The table 5 above showed that there are 36 or $48 \%$ respondents included in high level of literacy, 33 or $44 \%$ in medium level of literacy, and 6 or $8 \%$ in low level of literacy. While in investment variable, 40 or $53.33 \%$ of respondents included in high category, 32 or 
$43.67 \%$ in medium category, and 3 or $4 \%$ in low category. In saving and borrowing variable, most of the respondent, for about 27 or $36 \%$, is included in medium category. Whereas in insurance variable, there are 30 or $40 \%$ of the respondent included in low category of financial literacy. Thus it can be concluded that the respondents' financial literacy level in basic knowledge of financial and investment is included in high category. While the financial literacy level in saving and borrowing is included in medium category and insurance in low category.

\section{DISCUSSION}

\section{The effect of gender on the financial literacy}

The first hypothesis in this study is gender has influence on the financial literacy. The statistics test result on gender showed significance level for 0.061 or $>0.05$ which means it has no significant influence on financial literacy of Papuan MSMEs actor or H1 is rejected. This is supported by Delafrooz and Paim, (2011) and Laily (2012) who found that gender variable has no direct influence on the students' financial literacy. Gender cannot be used to measure someone's ability in managing financial. Different with Ansong and Gyensare (2012) who found that men is better in managing their financial than women. However, gender is not supposed to affect someone's behavior in managing their financial, because money can be managed well based on its necessity.

\section{The effect of latest education on the financial literacy}

The second hypothesis stated that the last education has significant influence on financial literacy of Papuan MSMEs actor. The regression test result showed that the significance level is 0.036 which means smaller than $\alpha=0.05$ or the hypothesis is accepted. This is supported by Amaliyah and Witiastuti, (2015) that stated people with higher education level must have higher literacy level. Most of the respondents, for about 45 people from total of 75 people, are having their last education background in high school. In this level, they are supposed to know about financial institution and know how to manage the financial in a good way.

\section{The effect of monthly income on the financial literacy}

The third hypothesis stated that the total of monthly income has no significant influence on the financial literacy of Papuan MSMEs actor. The regression test result showed that the significance level is bigger than $0.05(0.212>0.05)$ which means H3 is rejected. In this study, the cross tab result between monthly income and age is not showing any significant relationship toward financial literacy level. It is similar to Amaliyah and Witiastuti (2015) research that said the income level is not significant or not influence the financial literacy level. Therefore it can be concluded that monthly income has no effect on the financial literacy level of Papuan MSMEs actor.

\section{The effect of investment on the financial literacy}

The fourth hypothesis in this study is investment for Papuan MSMEs actor has significant influence on financial literacy. The regression test result showed that the significant level is less than $0.05(0.04<0.05)$ which means $\mathrm{H} 4$ is accepted. Papuan MSMEs actors tend to allocate their money to investment. Most of them are investing their money in jewelry or gold because they can sell it anytime they need money. This is supported by 
Silvy and Yulianti (2013) that found out the financial knowledge and experience can influence the family behavior on the financial planning. Therefore, investment has positive influence on the financial literacy level.

\section{The effect of saving and borrowing on the financial literacy}

The fifth hypothesis stated that saving and borrowing has influence the financial literacy level of Papuan MSMEs actors. The regression test result showed that the significance level is smaller than $0.05(0.007<0.05)$ which means H5 is accepted. Saving and borrowing are the main banking product known by Papuan MSMEs actors. Desiyanti (2016) stated that savings has the high of utility index value in MSME community. Moreover, the factor of bank interest also influence the saving and borrowing behavior of Papuan MSMEs actor. They will save their money when the interest level is high, and borrow some money when the interest is low.

\section{The effect of insurance on the financial literacy}

The sixth hypothesis stated that insurance has significant influence on the financial literacy. The regression test result showed the significance value is bigger from $\alpha=0.05$ $(0.008>\alpha=0.05)$ which means $\mathrm{H} 6$ is accepted. This result has significant influence because the majority of citizen, especially the Papuan MSMEs actor, understand about the insurance product. This research is in accordance with Wulandari and Narmaditya (2015) who stated that someone with high income has bigger potential in the insurance ownership rather than someone with low income. Insurance product is supposed to be needed by the Papuan MSMEs actors because it can protect the business if they had accident. Thus, Papuan MSMEs actors should be aware of the uncertain risks of their future business by using insurance products as the protection for their business.

\section{CONCLUSION}

Based on the result and discussion, it can be concluded that the financial literacy level of Papuan MSMEs actors in Jayapura city is included into the high category for the basic knowledge of finance and investment variables. While, for the variable of savings and borrowings it is included in medium category and the insurance variable in low category. Moreover, gender and monthly income have no significant influence on the financial literacy of Papuan MSME actors in Jayapura city. Meanwhile, the latest education, investment, saving and borrowing, and insurance have significant influence on the financial literacy of Papuan MSME actors in Jayapura City.

\section{SUGGESTION}

Due to the limitations of this study, the researchers suggest for futher research to add more independent variables, such as other banking products. The researchers also suggest to increase the sample, because insufficient samples may affect the validity and authenticity of the questionnaire. Also, it is also necessary to attention to the time of the questionnaire's spread in the market because it can interfere the transactions between buyers and sellers in the market. 


\section{REFERENCES}

Amaliyah, R., Witiastuti, R. S. (2015). Analisis Faktor yang Mempengaruhi Tingkat Literasi Keuangan di Kalangan UMKM Kota Tegal. "Management Analysis Journal”, 4(3). DOI: 10.15294/maj.v4i3.8876.

Ansong, A., Gyensare, M. A. (2012). Determinants of University Working-Students' Financial Literacy at the University of Cape Coast, Ghana. "International Journal of Business and Management", 7(9). DOI: 10.5539/ijbm.v7n9p126.

Aribawa, D. (2016). Pengaruh Literasi Keuangan terhadap Kinerja dan Keberlangsungan UMKM di Jawa Tengah. "Jurnal Siasat Bisnis", 20(1). DOI: 10.20885/jsb.vol20.iss1.art1.

Delafrooz, N., Paim, H. L. (2011). Determinants of financial wellness among Malaysia workers. "African Journal of Business Management", 5(24). DOI: 10.5897/AJBM10.1267.

Desiyanti, R. (2016). Literasi dan Inklusi Keuangan serta Indeks Utilitas UMKM di Padang. "BISMAN Jurnal Bisnis \& Manajemen", 2(2).

Margaretha, F., Pambudhi, R. A. (2015). Tingkat Literasi Keuangan pada Mahasiswa S-1 Fakultas Ekonomi. "Jurnal Manajemen Dan Kewirausahaan (Journal of Management and Entrepreneurship)", 17(1). DOI: 10.9744/jmk.17.1.76-85.

Otoritas Jasa Keuangan (2017). Survei Nasional Literasi dan Inklusi Keuangan 2016. Otoritas Jasa Keuangan.

Silvy, M., Yulianti, N. (2013). Sikap Pengelola Keuangan dan Perilaku Perencanaan Investasi Keluarga di Surabaya. "Journal of Business and Banking", 3(1). DOI: 10.14414/ jbb.v3i1.254.

Sucuahi, W. T. (2013). Determinants of Financial Literacy of Micro Entrepreneurs in Davao City. "International Journal of Accounting Research". DOI: 10.12816/0001127.

Welly, Kardinal, Juwita, R. (2018). Analisis Pengaruh Literasi Keuangan Terhadap Keputusan Investasi Di STIE Multi Data Palembang. ”Jurnal Ilmu Ekonomi”.

Wulandari, D., Narmaditya, B. S. (2015). Dampak Literasi Keuangan Pada Akses Layanan Keuangan: Studi Pada Kepemilikan Polis Asuransi di Malang. "Jurnal Ekonomi Dan Studi Pembangunan (JESP)", 7(1).

DOI: $10.7862 / \mathrm{rz} .2021 . \mathrm{mmr} .23$

The text was submitted to the editorial office: October 2021.

The text was accepted for publication: December 2021. 